\title{
Redox stratification drives enhanced growth in a deposit-feeding invertebrate: implications for aquaculture bioremediation
}

\author{
Georgina Robinson ${ }^{1,2, *}$, Gary S. Caldwell ${ }^{1}$, Clifford L. W. Jones ${ }^{2}$, \\ Matthew J. Slater ${ }^{1,3}$, Selina M. Stead ${ }^{1}$ \\ ${ }^{1}$ School of Marine Science and Technology, Newcastle University, Newcastle NE1 7RU, UK \\ ${ }^{2}$ Department of Ichthyology and Fisheries Science, Rhodes University, Grahamstown 6140, South Africa \\ ${ }^{3}$ Alfred-Wegener-Institute, Helmholtz Center for Polar and Marine Research, Am Handelshafen 12, 27570 Bremerhaven, Germany
}

\begin{abstract}
Effective and affordable treatment of waste solids is a key sustainability challenge for the aquaculture industry. Here, we investigated the potential for a deposit-feeding sea cucumber, Holothuria scabra, to provide a remediation service whilst concurrently yielding a high-value secondary product in a land-based recirculating aquaculture system (RAS). The effect of sediment depth, particle size and redox regime were examined in relation to changes in the behaviour, growth and biochemical composition of juvenile sea cucumbers cultured for $81 \mathrm{~d}$ in manipulated sediment systems, describing either fully oxic or stratified (oxic-anoxic) redox regimes. The redox regime was the principal factor affecting growth, biochemical composition and behaviour, while substrate depth and particle size did not significantly affect growth rate or biomass production. Animals cultured under fully oxic conditions exhibited negative growth and had higher lipid and carbohydrate contents, potentially due to compensatory feeding in response to higher microphytobenthic production. In contrast, animals in the stratified treatments spent more time feeding, generated faster growth and produced significantly higher biomass yields $\left(626.89 \pm 35.44 \mathrm{~g} \mathrm{~m}^{-2}\right.$ versus $449.22 \pm 14.24 \mathrm{~g} \mathrm{~m}^{-2}$; mean $\pm \mathrm{SE}$ ). Further, unlike in oxic treatments, growth in the stratified treatments did not reach maximum biomass carrying capacity, indicating that stratified sediment is more suitable for culturing sea cucumbers. However, the stratified sediments may exhibit reduced bioremediation ability relative to the oxic sediment, signifying a trade-off between remediation efficiency and exploitable biomass yield.
\end{abstract}

KEY WORDS: Sea cucumber - Holothuria scabra · Sandfish · Value-added aquaculture · Recirculating aquaculture $\cdot$ Bioturbation $\cdot$ Compensatory feeding

\section{INTRODUCTION}

Bioremediation - the biological treatment of waste streams and pollutants - is a widely established process, increasingly applied by a broad range of industries operating within varied environmental and ecological settings and constraints (Alexander 1999). In general, bioremediation technologies are bacteriadriven, with selective stimulation of the degrading

\footnotetext{
*Corresponding author: g.robinson3@ncl.ac.uk
}

activities of endogenous microbial populations, a fundamental concept underpinning the approach (Colleran 1997). Increasingly, bioremediation operations are seeking to add value to their processes by converting the derived biomass into exploitable products, e.g. feeds, fuels and high-value goods (Gifford et al. 2004, Muradov et al. 2014). Bioremediation strategies are being developed for and deployed in the aquaculture industry, primarily as a means to

() The authors 2015. Open Access under Creative Commons by Attribution Licence. Use, distribution and reproduction are unrestricted. Authors and original publication must be credited. 
capture nutrient leachates and suspended solids from effluent and sediments (Chávez-Crooker \& Obreque-Contreras 2010, Kim et al. 2013), but also to reduce pathogen discharge to the environment (Zhang et al. 2010).

The effective and affordable treatment of sediments and suspended solid wastes from intensive aquaculture operations remains a key sustainability challenge facing the industry. Land-based aquaculture operations, in particular recirculating aquaculture systems (RAS), offer the greatest potential to separate waste streams for downstream treatment. Despite the fact that concentrated solid wastes from closed recirculating aquaculture systems provide for a number of alternative waste management strategies, proportionally, research efforts have placed greater emphasis on the treatment of dissolved inorganic nutrients. The processing and/or removal of particulate organic wastes, either in situ or ex situ, poses an environmental threat and remains a significant cost to the industry. If added economic value is secured as part of the process, it will provide further incentives for the operators to adopt best environmental farming practices.

Deposit-feeding polychaetes and sea cucumbers are prime candidates for value-added bioremediation of aquaculture waste solids due to their ability to assimilate particulate organic wastes (comprising decaying feed and faeces) derived from intensive landbased aquaculture (Palmer 2010, Watanabe et al. 2012). Furthermore, deposit-feeders accelerate the depletion of organic matter reservoirs through bioturbation (Yingst 1976, Moriarty 1982, Baskar 1994, Mercier et al. 1999); thereby improving sediment quality and contributing to nutrient remineralisation (Aller 1994, Aller \& Aller 1998, Kristensen 2000, Uthicke 2001, Mermillod-Blondin \& Rosenberg 2006). The commercially valuable sea cucumber, Holothuria scabra (Echinodermata: Holothuroidae), commonly referred to as sandfish, is a promising candidate for cultivation as a high-value secondary product in effluent treatment systems, due to its natural ecological affinity for organically rich sediments in tropical environments. It is currently the most valuable tropical sea cucumber species, commanding high prices (up to US\$ $1668 \mathrm{~kg}^{-1}$ ) and a strong market demand (Purcell 2014); however, wild stocks are over-exploited, and the species is registered as endangered (Purcell et al. 2014). Aquaculture production is considered the only viable means to fulfil market demand.

Sandfish require a substrate for optimal growth in culture tanks; therefore, determination of the opti- mum physicochemical substrate parameters is a prerequisite for the successful design of land-based bioremediation applications (Robinson et al. 2013). A number of factors affect the rate of organic matter mineralisation in sediments, including organic matter characteristics, temperature, $\mathrm{pH}$, redox potential, bioturbation, and sediment depth and grain size (Stahlberg et al. 2006). The dynamics between sediment mineralisation and bioturbation processes are characterised by strong feedback loops between deposit-feeders, their food, and their microbial and chemical environment (Herman et al. 1999). Depositfeeder-microbial (i.e. detrital) food chains offer a great potential for manipulation to improve their overall ecological and commercial efficiency in terms of organic loading and biomass production (Moriarty 1987). However, it is essential to improve understanding of the physicochemical and biological processes that govern the degradation kinetics of organic matter in detrital food chains and sedimentbased aquaculture effluent treatment systems integrating deposit-feeders (Pullin 1987, Stahlberg et al. 2006).

The supplemental delivery of external electron acceptors is one method used for in situ bioremediation technologies to alleviate the constraints imposed by the naturally slow mineralisation process. Increased oxidant supply via the percolation of oxygen-rich water is commonly used to stimulate aerobic decomposition (Colleran 1997); however, it remains unclear how oxidant supply and sediment manipulation affects waste availability and remediation efficiency in such systems. Furthermore, it is anticipated that this approach may have negative consequences for the nutritional environment of deposit-feeders, which inhabit redox-stratified sediments in the wild (Lopez \& Levinton 1987).

This study examines the effect of manipulated surficial sediment systems describing fully oxic versus stratified oxic-anoxic conditions, sediment particle size and depth on the growth and carrying capacity-defined here as the maximum sustainable population density supported by a given set of environmental factors - of an invertebrate (sea cucumber) deposit-feeder (Grassle \& Grassle 1974, Tenore 1981). A number of studies have examined the effects of substrate particle size and depth on the growth and survival of sandfish (Battaglene et al. 1999, Mercier et al. 1999, Pitt et al. 2001); however, the effects of other physical parameters or factor interactions have not been investigated. From the empirical evidence, inferences on whether $H$. scabra can increase the overall assimilative capacity of an 
Table 1. Description of the experimental treatments. Fine particle size: 125-250 $\mu \mathrm{m}$; medium particle size: $250-500 \mu \mathrm{m}$

\begin{tabular}{|lccccc|}
\hline $\begin{array}{l}\text { Treat- } \\
\text { ment } \\
\text { no. }\end{array}$ & $\begin{array}{c}\text { Tank } \\
\text { structure }\end{array}$ & Aeration & $\begin{array}{c}\text { Factor 1: } \\
\text { redox } \\
\text { regime }\end{array}$ & $\begin{array}{c}\text { Factor 2: } \\
\text { sediment depth } \\
(\mathrm{cm})\end{array}$ & $\begin{array}{c}\text { Factor 3: } \\
\text { particle } \\
\text { size }\end{array}$ \\
\hline 1 & Plenum & Airlift pump & Oxic & 2 & Fine \\
2 & Plenum & Airlift pump & Oxic & 2 & Medium \\
3 & Plenum & Airlift pump & Oxic & 4 & Fine \\
4 & Plenum & Airlift pump & Oxic & 4 & Medium \\
5 & No plenum & Airstone & Oxic-anoxic & 2 & Fine \\
6 & No plenum & Airstone & Oxic-anoxic & 2 & Medium \\
7 & No plenum & Airstone & Oxic-anoxic & 4 & Fine \\
8 & No plenum & Airstone & Oxic-anoxic & 4 & Medium \\
\hline
\end{tabular}

aquaculture effluent treatment system, either directly via the consumption and assimilation of particulate organic matter or indirectly through the stimulation of benthic microbial metabolism, can be determined. This information is important for understanding the benefits deposit-feeding invertebrates like the sea cucumber can have on mitigating the environmental impacts of aquaculture on its aquatic environment.

\section{MATERIALS AND METHODS}

\section{Animal husbandry and experimental conditions}

The study was conducted at HIK Abalone Farm (Pty) Ltd in Hermanus, on the southwest coast of South Africa $\left(34^{\circ} 26^{\prime} 04.35^{\prime \prime} \mathrm{S}\right.$; $\left.19^{\circ} 13^{\prime} 12.51^{\prime \prime} \mathrm{E}\right)$ between 20 March and 9 June 2012. A total of 2000 hatchery-reared juvenile Holothuria scabra weighing $2 \mathrm{~g}$ each were imported from a commercial hatchery (Madagascar Holothurie S.A., Madagascar) on 3 November 2011 and quarantined in a biosecure facility for $6 \mathrm{wk}$ in accordance with South African importation and scientific investigations licences. Following the quarantine period and prior to experimentation, the animals were held in a recirculating aquaculture system in tanks filled with $4.0 \mathrm{~cm}$ of calcium carbonate sand sediment and were fed a $34 \%$ protein commercial abalone weaning diet (S34 Abfeed $^{\circledR}, 1.0 \mathrm{~mm}$ sugar grain pellet; Marifeed).

A $2 \times 2 \times 2$ factorial design was used to investigate the response of $H$. scabra to:

(1) the sediment redox regime (oxic versus oxicanoxic),

(2) sediment depth $(2$ and $4 \mathrm{~cm})$ and

(3) sediment particle size (fine: $125-250 \mu \mathrm{m}$; medium: $250-500 \mu \mathrm{m}$; Table 1). Redox stratified (oxicanoxic) sediments were intended to mimic the redox state of sediments in the natural habitat of $H$. scabra which exhibit a shallow oxic-anoxic interface below which the sediment remains anoxic (Michio et al. 2003, Wolkenhauer et al. 2010). Substrate particle size and depth were included as experimental factors, as they can affect organic matter content and the distribution of microbial communities that mediate organic matter decomposition and biogeochemical transformations. Eight experimental treatments were allocated to 32 polyethylene tanks (455 $\times$ $328 \times 175 \mathrm{~mm}$ ) using a randomised block design of 8 tanks distributed in 4 blocks with 1 replicate per block.

Tanks were supplied with heated coastal seawater at a flow rate of $0.75 \mathrm{l} \mathrm{min}^{-1} \operatorname{tank}^{-1}$ filtered through a recirculating system comprising a composite sand filter, protein skimmer and biofilter. Aeration was supplied continuously, except during feeding when the air and water supplies were interrupted for $15 \mathrm{~min}$ to allow the feed to settle. Sea cucumbers were fed a $34 \%$ protein commercial abalone weaning diet (S34 Abfeed $^{\circledR}, 1.0 \mathrm{~mm}$ sugar grain pellet; Marifeed) once per day at 16:00 h. This reference diet was used to provide a reproducible baseline against which to compare any subsequent feeding trials using aquaculture wastes as feeds. Feeding was standardised across experimental treatments: daily feed rations were calculated at $1 \%$ of the total tank biomass and adjusted every 2 wk based on predicted biomass gains in between weight assessments (Battaglene et al. 1999). Decaying uneaten food and any arising white bacterial patches were removed by siphoning every $48 \mathrm{~h}$ (present in oxic-anoxic treatments only). All tanks were cleaned once per month; tank walls were manually scrubbed to remove the biofilm and any epiphytic algae or cyanobacteria. Experimental tanks were subjected to a natural photoperiod of $10 \mathrm{~h}$ light:14 h dark (07:40 to 17:40 h light, local time).

The sediment consisted of calcium carbonate 'builders sand' sourced from a commercial dune quarry (SSB Mining). The sediment was sieved to achieve the requisite particle sizes using a series of decreasing nylon mesh sizes (500, 250 and $125 \mu \mathrm{m}$.) An internal tank liner made from $95 \%$ shade cloth was used to contain the sediment in all tanks (Fig. 1). Oxic treatment tanks $(\mathrm{n}=16)$ were fitted with a plastic grid partition with perforations of $2 \mathrm{~cm}^{2}$ supported $4.5 \mathrm{~cm}$ above the tank base to create a sediment-free plenum (false bottom) (Jaubert 2008) directly under the liner. 
A) Fully oxic sediment tank

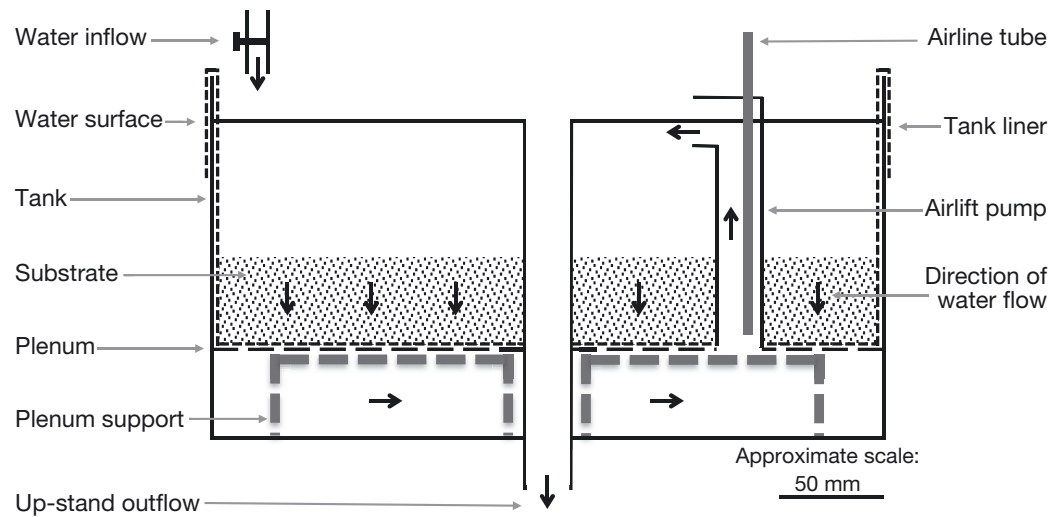

B) Redox stratified (oxic-anoxic) sediment tank

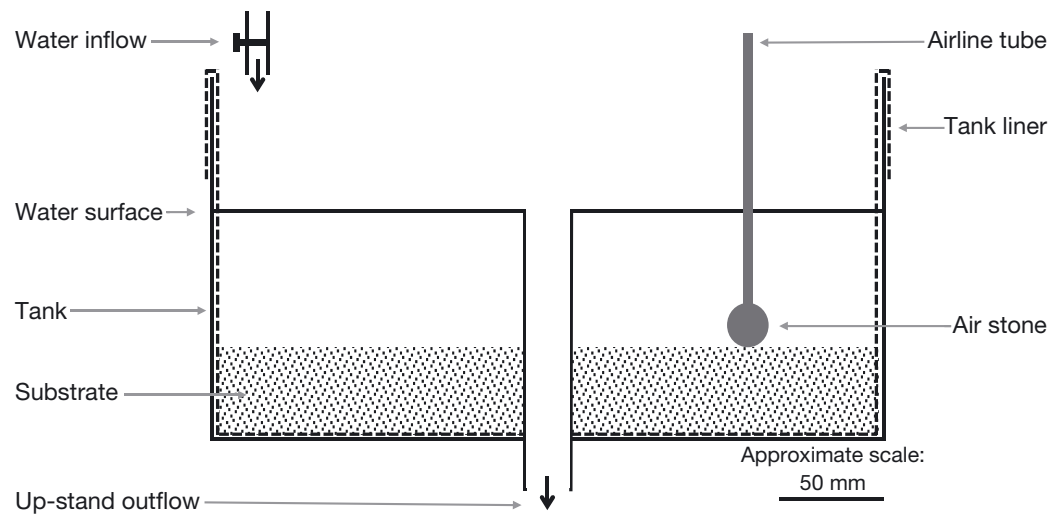

Fig. 1. Schematic diagram of the tank design used to create the 2 different sediment redox regimes. (A) The oxic treatment tanks were fitted with a plenum, and an airlift pump was used to circulate oxygenated water downwards through the sediment to maintain the sediment under a fully oxic regime. (B) In the oxic-anoxic treatment tanks, there was no plenum or water movement through the sediment, so a naturally stratified oxic-anoxic sediment developed; dissolved oxygen levels were maintained with an airstone

An airlift pump was used to circulate oxygenated water downwards through the sediment, maintain the sediment under a fully oxic regime and maintain dissolved oxygen levels within the water column. The water movement was sufficiently gentle as to cause no particle movement within the sand. In the stratified oxic-anoxic treatment tanks, the sediment was directly exposed to the base of the tanks (i.e. no plenum and no water movement through the sediment) so that naturally stratified oxic-anoxic sediment developed. Aeration was provided to the oxic-anoxic tanks using airstones to maintain dissolved oxygen levels within the water column (Table 1).

Prior to stocking into experimental tanks, the juvenile sea cucumbers $(\mathrm{n}=128)$ were suspended in mesh bags for $24 \mathrm{~h}$ to ensure gut contents were evacuated prior to weighing. They were then drained on a damp cloth for $1 \mathrm{~min}$, weighed to the nearest $0.01 \mathrm{~g}$ and photographed for individual photo-identification to permit monitoring of individual growth rates (Raj 1998). Animals with a mean $( \pm \mathrm{SE})$ weight of $7.3 \pm 0.07 \mathrm{~g}$ ind..$^{-1}$ were allocated randomly to 32 groups of 4 individuals per group. Each individual was gut-evacuated for $24 \mathrm{~h}$ and reweighed every $27 \mathrm{~d}$ over the $81 \mathrm{~d}$ experimental period. Wet weight data were used to calculated specific growth rate (SGR), growth rate and coefficient of variation (CV) as follows:

SGR $\left(\% d^{-1}\right)=100\left(\ln W_{2}-\ln W_{1}\right) / T(1)$

Growth rate $\left(\mathrm{g} \mathrm{d}^{-1}\right)=\left(W_{2}-W_{1}\right) / T$

$\mathrm{CV}(\%)=100 \times(\mathrm{SD} / \overline{\mathrm{X}})$

where $W_{1}$ and $W_{2}$ are initial and final wet body weight $(\mathrm{g})$ of sea cucumbers in each experimental tank, $T$ is the duration of the experiment (days); SD is the standard deviation in body weight and $\bar{x}$ is the mean wet weight (g) of sea cucumbers in each experimental tank for a particular sampling period.

\section{Behavioural observations}

Behavioural observations were carried out over 3 consecutive $24 \mathrm{~h}$ periods in the penultimate week of the study. Observations were made at $4 \mathrm{~h}$ intervals, commencing at noon. Red light was used to facilitate night time observations. During each observation period, each tank was observed for 2 min and the number of animals in each burial state and their levels of activity were recorded (Table 2).

\section{Proximate composition analysis}

At the end of the trial all animals from 3 of the 4 replicate tanks for each treatment were pooled and homogenised, thereby creating 1 composite sample per tank, which was frozen at $-20^{\circ} \mathrm{C}$. The composite samples were then lyophilised at $-80^{\circ} \mathrm{C}$, ground to a fine powder $(\sim 50 \mu \mathrm{m})$ with a pestle and mortar, and their proximate composition was analysed according to the Association of Official Analytical Chemists' (AOAC) official methods (AOAC 2010). Moisture 
Table 2. Holothuria scabra. Definition of sea cucumber behaviour categorised into burial state and activity according to Wolkenhauer (2008)

\begin{tabular}{|ll|}
\hline Behaviour & Definition \\
\hline Burial state & \\
Buried & Entire body under the sediment surface \\
Semi-buried & $>50 \%$ of the body under sediment surface \\
On the & Entire body on sediment surface \\
surface & \\
Activity & Animal is inactive with no movement \\
Resting & observed \\
Feeding & Animal is actively feeding on sediment or \\
& walls; tentacles are exposed, and head \\
& performs sweeping movements \\
\hline
\end{tabular}

was determined by weight loss after drying at $95^{\circ} \mathrm{C}$ for $72 \mathrm{~h}$ (AOAC Method 934.01), while ash was determined by weight loss on combustion after ashing in a furnace for $4 \mathrm{~h}$ at $550^{\circ} \mathrm{C}$ (AOAC Method 942.05). Crude protein was analysed in a LECO Truspec nitrogen analyser using the Dumas combustion method (AOAC Method 990.03). Crude fibre was analysed using a Dosi-Fibre machine (AOAC Method 978.10). Gross energy was determined using a LECO AC500 automatic bomb calorimeter (LECO Corporation). Carbohydrate was calculated indirectly by adding the percentage values determined for crude protein, lipid, crude fibre and ash, and subtracting the total from 100.

\section{Water and sediment analysis}

Water-quality parameters were recorded weekly from water sampled adjacent to the outflow of each tank during mid-morning. Temperature and $\mathrm{pH}$ were measured using a $\mathrm{pH}$ meter (YSI Inc. Model No. $60 / 10$ FT). Dissolved oxygen concentration was measured using an oxygen meter (YSI Inc. Model No. 55D). Total ammonia nitrogen $\left(\mathrm{NH}_{4}-\mathrm{N}_{i} \mathrm{TAN}\right)$ was determined using the method of Solorzano (1969). Nitrite concentration was measured using a commercially available test kit (Merck nitrite test kit, Cat. No. 1.14776.0001) with colour absorbance read by a spectrophotometer (Prim Light, Secomam). Absorbance was converted into the concentration of total ammonia nitrogen or nitrite using the coefficients derived from standard curves of least-squared linear regression.

At the end of the trial on Day 81, the sediment reduction-oxidation (redox) potential was measured in millivolts by inserting a redox probe (Eutech Instruments $\mathrm{pH} 6+$ portable meter) to the base of the sand sediment. Readings were taken following stabilisation (after approximately $5 \mathrm{~min}$ ). Since technological limitations did not allow for a full vertical profile measurement of the redox potential of the sediment, in addition, 4 replicate cores were taken from different positions within each tank using a $10 \times$ $1 \mathrm{~cm}$ (length $\times$ diameter) Perspex coring device and the depth from the sediment surface to the oxicanoxic interface was recorded. The mean depth $(\mathrm{cm})$ of anoxic sediment in each tank was converted to the percentage of anoxic sediment in the core to allow direct comparisons between treatments, since sediment depth varied. Sediment samples were collected from the upper $3 \mathrm{~mm}$ of 3 replicate tanks and dried to a constant weight at $50^{\circ} \mathrm{C}$ for $48 \mathrm{~h}$. Samples were analysed for organic carbon and total nitrogen content using a LECO TruSpec micro elemental analyser prior to and after carbonate removal. Carbonates were removed by fuming with $2 \mathrm{M} \mathrm{HCl}$ for $48 \mathrm{~h}$, after which the samples were rinsed 3 times with distilled water, dried to constant weight and re-analysed for total organic carbon. Carbon to nitrogen ratios were then calculated for each replicate sample. Total chlorophyll concentration was determined using $90 \%$ acetone extraction before the first spectrophotometric step, and the concentrations of chlorophyll $a$, $b$ and $c$ were calculated using the trichromatic equation of Jeffrey \& Welschmeyer (1997).

\section{Statistical analyses}

Mean biomass of individual $H$. scabra (per replicate tank) and mean (per replicate tank) water and sediment characteristics were tested for normality using Shapiro-Wilk's test and for homogeneity of variance using Levene's test. Data that met the test assumptions were compared across the 8 experimental treatments using multifactor analysis of variance (ANOVA), and Duncan's multiple range tests were used to compare differences among means of dependent variables (Quinn \& Keough 2012). Data that did not meet the test assumptions were log transformed before analysis. If log-transformed data did not meet the assumption of homogeneity of variance either, a KruskalWallis 1-way ANOVA was used to test for significant differences in the means between treatments. Differences were considered significant at $p<0.05$. Mean values are given $\pm \mathrm{SE}$.

The numbers of animals engaging in each specific behaviour were averaged to give the mean number 
Table 3. Summary of sediment characteristics subjected to 2 contrasting redox regimes, each with different depths and particle sizes (fine particles: 125-250 $\mu \mathrm{m}$; medium particles: $250-500 \mu \mathrm{m}$ ). Data are presented as means \pm SE. Different superscripts indicate significant differences (multifactor ANOVA, $\mathrm{p}<0.05$ ) identified by Duncan's multiple range tests. -: not applicable

\begin{tabular}{|lcccccccc|}
\hline Redox regime & $\begin{array}{c}\text { Depth } \\
(\mathrm{cm})\end{array}$ & $\begin{array}{c}\text { Particle } \\
\text { size }\end{array}$ & $\begin{array}{c}\text { Total chloro- } \\
\left.\text { phyll }(\mu \mathrm{g} \mathrm{g})^{-1}\right)\end{array}$ & $\begin{array}{c}\text { Redox poten- } \\
\text { tial }(\mathrm{mV})\end{array}$ & $\begin{array}{c}\text { Anoxic } \\
\text { sediment }(\%)\end{array}$ & $\begin{array}{c}\text { Organic } \\
\text { carbon }(\%)\end{array}$ & $\begin{array}{c}\text { Total nitrogen } \\
(\%)\end{array}$ & $\begin{array}{c}\text { C/N ratio } \\
\text { Oxic }\end{array}$ \\
\hline & 2 & Fine & $15.58 \pm 5.05$ & $169.33 \pm 40.92$ & $-^{\mathrm{a}}$ & $0.26 \pm 0.01^{\mathrm{c}}$ & $0.040 \pm 0.000^{\mathrm{c}}$ & $6.49 \pm 0.25^{\mathrm{c}}$ \\
Oxic & 2 & Medium & $7.44 \pm 0.97$ & $158.08 \pm 58.18$ & $-^{\mathrm{a}}$ & $0.69 \pm 0.06^{\mathrm{a}}$ & $0.030 \pm 0.003^{\mathrm{a}}$ & $20.99 \pm 2.54^{\mathrm{ab}}$ \\
Oxic & 4 & Fine & $9.83 \pm 3.62$ & $137.44 \pm 41.80$ & $-^{\mathrm{a}}$ & $0.39 \pm 0.01^{\mathrm{cd}}$ & $0.030 \pm 0.000^{\mathrm{a}}$ & $13.03 \pm 0.49^{\mathrm{d}}$ \\
Oxic & 4 & Medium & $8.67 \pm 1.65$ & $121.88 \pm 41.13$ & $-^{\mathrm{a}}$ & $0.56 \pm 0.00^{\mathrm{ab}}$ & $0.033 \pm 0.000^{\mathrm{a}}$ & $18.52 \pm 0.16^{\mathrm{a}}$ \\
Oxic-anoxic & 2 & Fine & $5.72 \pm 0.15$ & $95.83 \pm 13.60$ & $81.97 \pm 8.02^{\mathrm{b}}$ & $0.45 \pm 0.03^{\mathrm{bd}}$ & $0.027 \pm 0.003^{\mathrm{a}}$ & $17.39 \pm 1.78^{\mathrm{a}}$ \\
Oxic-anoxic & 2 & Medium & $6.23 \pm 3.06$ & $101.25 \pm 57.81$ & $76.98 \pm 9.26^{\mathrm{b}}$ & $0.69 \pm 0.05^{\mathrm{a}}$ & $0.030 \pm 0.000^{\mathrm{a}}$ & $23.09 \pm 1.80^{\mathrm{b}}$ \\
Oxic-anoxic & 4 & Fine & $2.24 \pm 0.22$ & $41.81 \pm 42.40$ & $93.34 \pm 1.00^{\mathrm{b}}$ & $0.59 \pm 0.09^{\mathrm{ab}}$ & $0.027 \pm 0.003^{\mathrm{a}}$ & $21.74 \pm 0.83^{\mathrm{ab}}$ \\
Oxic-anoxic & 4 & Medium & $2.93 \pm 0.51$ & $24.38 \pm 46.38$ & $79.74 \pm 9.26^{\mathrm{b}}$ & $0.58 \pm 0.02^{\mathrm{ab}}$ & $0.020 \pm 0.000^{\mathrm{b}}$ & $29.15 \pm 0.91^{\mathrm{e}}$ \\
\hline
\end{tabular}

of animals per replicate tank in each burial state or activity at 6 different time intervals and analysed using repeated measures ANOVA. A multivariate approach was used with redox regime, sediment depth and particle size as categorical predictors and the mean number of animals engaged in a specific behaviour at each time period as the dependent variable (within effects). Although the assumptions for normality and homogeneity of variance were not met using the Shapiro-Wilk's and Levene's tests, even with transformed data, repeated measures ANOVA was still deemed sufficiently robust to compare treatment means over time (Moser \& Stevens 1992). A Mauchly's test examined sphericity of the variancecovariance matrix. As sphericity was violated in the majority of cases, a Greenhouse-Geisser epsilon correction was used to adjust $F$ statistics conservatively. Significant differences among treatment means were identified using a Tukey's honestly significant difference (HSD) post hoc test.

\section{RESULTS}

\section{Water quality}

The mean water temperature was $25.71 \pm 0.05^{\circ} \mathrm{C}$ and varied between 25.18 and $26.40^{\circ} \mathrm{C}$ over the experimental period. $\mathrm{pH}$ ranged from 8.01 to 8.43 , and salinity was constant at $35 \mathrm{~g} \mathrm{l}^{-1}$. Dissolved oxygen concentrations varied between 5.77 and $6.97 \mathrm{mg} \mathrm{l}^{-1}$ (mean: $6.6 \pm 0.04 \mathrm{mg} \mathrm{l}^{-1}$ ). Total ammonia concentrations varied between 17.06 and $64.21 \mathrm{\mu g} \mathrm{l}^{-1}$ (mean: $29.00 \pm 1.74 \mu \mathrm{g} \mathrm{l}^{-1}$ ) and nitrite concentrations ranged from 17.68 to $37.00 \mathrm{\mu g} \mathrm{l}^{-1}$ (mean: $26.01 \pm$ $0.78 \mathrm{\mu g} \mathrm{l}^{-1}$ ). There were no significant differences in water-quality parameters between treatments $(p>$ $0.05)$, with the exception of Treatment 4 that exhibited a significantly lower nitrite concentration over the experimental period (multifactor ANOVA, $F_{1,24}=$ $6.32, p=0.019$ ), which was explained by the interaction between sediment depth and the manipulated redox regime; sediment particle size made no significant contribution.

\section{Sediment characteristics}

The sediment core profiles confirmed that the incorporation of a plenum into the tank design maintained fully oxic conditions (Treatments 1-4); hereafter referred to as oxic. In contrast, in tanks without a plenum, $83.01 \pm 3.80 \%$ of the sediment profile was anoxic (Treatments 5-8); hereafter referred to as oxic-anoxic (multifactor ANOVA, $F_{1,24}=465.53$, $\mathrm{p}<$ 0.001 ). The redox potential of the oxic treatments was significantly higher $(147.98 \pm 21.00 \mathrm{mV})$ compared with the oxic-anoxic treatments $\left(67.27 \pm 21.18 \mathrm{mV}_{\text {; }}\right.$ multifactor ANOVA, $F_{1,24}=5.81, \mathrm{p}=0.028$; Table 3).

The sediment redox regime significantly affected the total chlorophyll concentration on the sediment surface (multifactor ANOVA, $F_{1,21}=13.42, \mathrm{p}=0.001$; Table 3), with higher concentrations in the oxic treatments $\left(10.03 \pm 1.51 \mathrm{\mu g} \mathrm{g}^{-1}\right)$ compared with oxicanoxic treatments $\left(4.29 \pm 0.74 \mu \mathrm{g} \mathrm{g}^{-1}\right)$, indicating greater microphytobenthic production. Observations of the sediment surface between the contrasting redox regimes also supported this quantitative data: oxic treatments were characterised by markedly thicker growth of benthic diatoms (Nitzschia and Navicula species) and Oscillatoria cyanobacteria.

Levels of organic carbon in the sediment were generally low, ranging from $0.26 \pm 0.01$ to $0.69 \pm 0.06 \%$, although the percentage of organic carbon was significantly higher in sediments with medium particle sizes $(0.63 \pm 0.03 \%)$ than in those with fine particles $\left(0.42 \pm 0.04 \%\right.$; multifactor ANOVA, $F_{1,16}=42.15, \mathrm{p}<$ 0.001 ; Table 3). Sediment redox regime, depth and 
Table 4. Holothuria scabra. Summary of growth performance of sea cucumbers subjected to 2 substrates with contrasting redox regimes, each with different depths and particle sizes (fine particles: $125-250 \mu \mathrm{m}$; medium particles: $250-500 \mu \mathrm{m}$ ). Data are presented as means \pm SE. Different superscripts indicate significant differences (multifactor ANOVA, $p<0.05$ ) identified by Duncan's multiple range tests. SGR: specific growth rate; CV: coefficient of variation

\begin{tabular}{|c|c|c|c|c|c|c|c|c|c|}
\hline $\begin{array}{l}\text { Redox } \\
\text { regime }\end{array}$ & $\begin{array}{l}\text { Depth } \\
\text { (cm) }\end{array}$ & $\begin{array}{l}\text { Particle } \\
\text { size }\end{array}$ & $\begin{array}{c}\text { Survival } \\
(\%)\end{array}$ & $\begin{array}{c}\text { Initial } \\
\text { weight }(g)\end{array}$ & $\begin{array}{c}\text { Final weight } \\
\text { (g) }\end{array}$ & $\begin{array}{l}\text { Growth } \\
\text { rate }\left(\mathrm{g} \mathrm{d}^{-1}\right)\end{array}$ & $\begin{array}{c}\text { SGR } \\
\left(\% d^{-1}\right)\end{array}$ & $\begin{array}{c}\text { Biomass } \\
\text { density }\left(\mathrm{g} \mathrm{m}^{-1}\right)\end{array}$ & $\begin{array}{l}\mathrm{CV} \\
(\%)\end{array}$ \\
\hline Oxic & 2 & Fine & 100 & $7.16 \pm 0.22$ & $17.20 \pm 0.67^{\mathrm{a}}$ & $0.12 \pm 0.01^{\mathrm{ab}}$ & $1.03 \pm 0.06^{\mathrm{a}}$ & $461.68 \pm 18.01^{a}$ & $23.11 \pm 4.34^{\mathrm{ab}}$ \\
\hline Oxic & 2 & Medium & 100 & $7.38 \pm 0.10$ & $16.09 \pm 1.04^{\mathrm{a}}$ & $0.11 \pm 0.01^{\mathrm{a}}$ & $0.95 \pm 0.08^{a}$ & $432.00 \pm 27.85^{a}$ & $11.58 \pm 1.90^{\mathrm{a}}$ \\
\hline Oxic & 4 & Fine & 100 & $7.05 \pm 0.17$ & $16.90 \pm 1.35^{\mathrm{a}}$ & $0.12 \pm 0.01^{\mathrm{a}}$ & $1.00 \pm 0.05^{\mathrm{a}}$ & $453.67 \pm 36.37^{a}$ & $21.28 \pm 7.61^{\mathrm{ab}}$ \\
\hline Oxic & 4 & Medium & 100 & $7.18 \pm 0.10$ & $17.97 \pm 1.36^{\mathrm{ab}}$ & $0.13 \pm 0.02^{\mathrm{ab}}$ & $1.10 \pm 0.09^{\mathrm{ab}}$ & $449.53 \pm 38.38^{a}$ & $19.03 \pm 4.72^{\mathrm{ab}}$ \\
\hline Oxic-anoxic & 2 & Fine & 100 & $7.60 \pm 0.06$ & $23.97 \pm 2.72^{\mathrm{bc}}$ & $0.20 \pm 0.03^{\mathrm{ab}}$ & $1.36 \pm 0.13^{\mathrm{ab}}$ & $643.56 \pm 72.99^{b}$ & $27.90 \pm 7.58^{\mathrm{ab}}$ \\
\hline Oxic-anoxic & 2 & Medium & 100 & $7.09 \pm 0.09$ & $22.35 \pm 2.07^{\mathrm{abc}}$ & $0.20 \pm 0.03^{\mathrm{bc}}$ & $1.30 \pm 0.15^{\mathrm{ab}}$ & $600.03 \pm 55.60^{\mathrm{ab}}$ & $51.82 \pm 7.34^{\mathrm{c}}$ \\
\hline Oxic-anoxic & 4 & Fine & 100 & $7.16 \pm 0.33$ & $26.66 \pm 2.83^{c}$ & $0.24 \pm 0.04^{\mathrm{c}}$ & $1.54 \pm 0.23^{\mathrm{b}}$ & $715.76 \pm 75.97^{b}$ & $34.00 \pm 5.64^{b}$ \\
\hline Oxic-anoxic & 4 & Medium & 100 & $7.80 \pm 0.25$ & $20.42 \pm 2.86^{\mathrm{abc}}$ & $0.16 \pm 0.04^{\mathrm{bc}}$ & $1.10 \pm 0.20^{\mathrm{ab}}$ & $548.20 \pm 76.84^{\mathrm{ab}}$ & $23.36 \pm 6.73^{\mathrm{ab}}$ \\
\hline
\end{tabular}

particle size interacted to affect total nitrogen content (multifactor ANOVA, $F_{1,16}=8.33, \mathrm{p}=0.011$ ) and the carbon to nitrogen ratio (multifactor ANOVA, $F_{1,16}=7.85, \mathrm{p}=0.013 ;$ Table 3$)$. The redox regime explained the oxic-anoxic treatments' higher organic carbon content $(0.58 \pm 0.04 \%$ versus $0.47 \pm 0.05 \%$; multifactor ANOVA, $F_{1,16}=10.72, \mathrm{p}=0.005$ ), while oxic treatments had a higher total nitrogen content $(0.033 \pm 0.001 \%$ versus $0.026 \pm 0.001 \%$; multifactor ANOVA, $\left.F_{1,16}=27.00, \mathrm{p}<0.001\right)$ and resulted in higher carbon to nitrogen ratios in the oxic-anoxic treatments $(22.84 \pm 1.40 \%$ versus $14.76 \pm 1.77 \%$; multifactor ANOVA, $F_{1,16}=71.29, \mathrm{p}<0.001$ ).

\section{Growth and survival}

There were no significant differences in mean sea cucumber biomass $(29.20 \pm 2.29 \mathrm{~g})$ between treatments at the start of the experiment (Kruskal-Wallis, $H_{7,32}=11.17, \mathrm{p}=0.13$ ). Survival was $100 \%$ in all treatments (Table 4). The final mean growth rate of animals reared in the oxic-anoxic treatments was significantly higher at $0.20 \pm 0.02 \mathrm{~g} \mathrm{~d}^{-1}$ compared with $0.12 \pm 0.01 \mathrm{~g} \mathrm{~d}^{-1}$ for animals in oxic treatments (multifactor ANOVA, $F_{1,24}=19.59, \mathrm{p}<0.001$ ). The growth rate of juveniles in oxic treatments decreased over time from $0.23 \pm 0.02 \mathrm{~g} \mathrm{~d}^{-1}$ between Days 0 and 27 to a negative growth rate of $-0.01 \pm 0.02 \mathrm{~g} \mathrm{~d}^{-1}$ between Days 54 and 81 (Fig. 2). Conversely, animals reared in oxic-anoxic treatments maintained an initial growth rate $>0.2 \mathrm{~g} \mathrm{~d}^{-1}$, with a slight reduction to $0.14 \pm 0.04 \mathrm{~g} \mathrm{~d}^{-1}$ between Days 54 and 81 (Fig. 2). Biomass from oxic sediments reached a maximum mean density of $454.84 \pm 14.30 \mathrm{~g} \mathrm{~m}^{-2}$ on Day 54 , after which no further increase in biomass was observed (Fig. 3). The final biomass density of animals in the oxic-anoxic treatments was significantly higher at

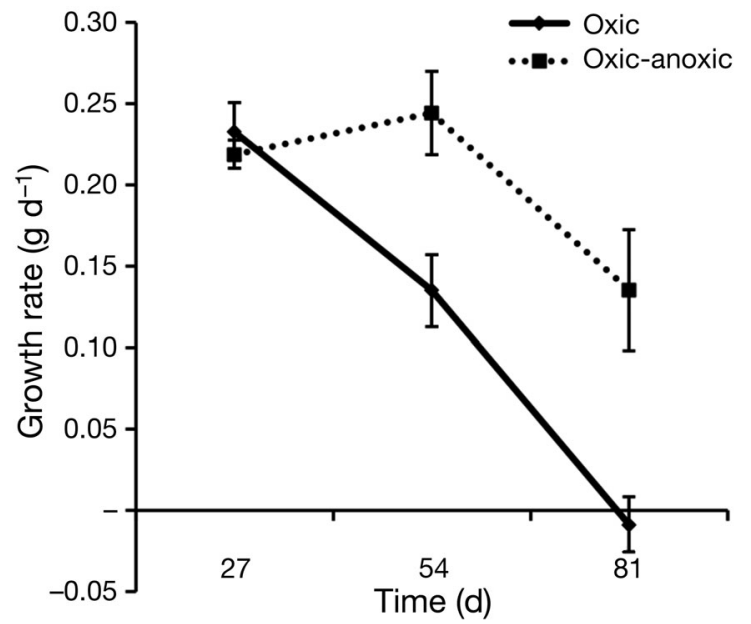

Fig. 2. Mean $( \pm \mathrm{SE})$ growth rate per sampling period of Holothuria scabra $(\mathrm{n}=4)$ reared under 2 contrasting sediment redox regimes: fully aerobic (oxic) and stratified (oxicanoxic)

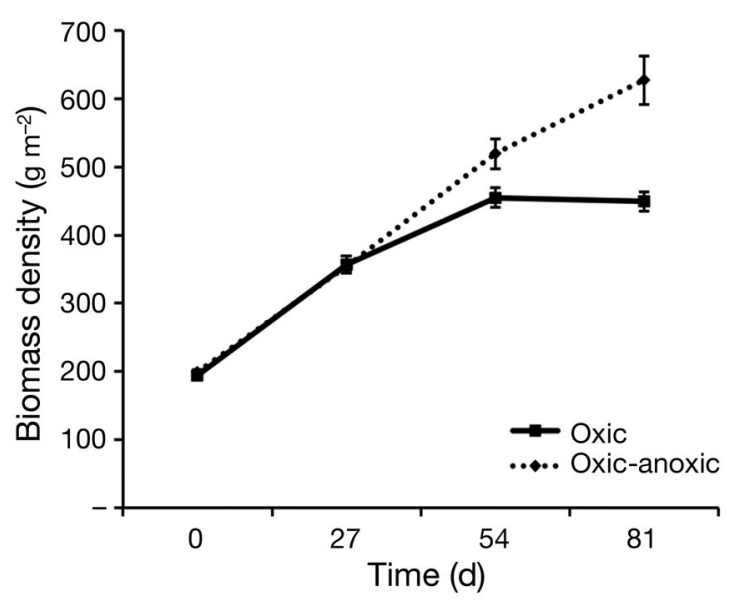

Fig. 3. Mean $( \pm \mathrm{SE})$ cumulative biomass density of Holothuria scabra $(\mathrm{n}=4)$ reared for $81 \mathrm{~d}$ under 2 contrasting sediment redox regimes: fully aerobic (oxic) and stratified (oxic-anoxic) 


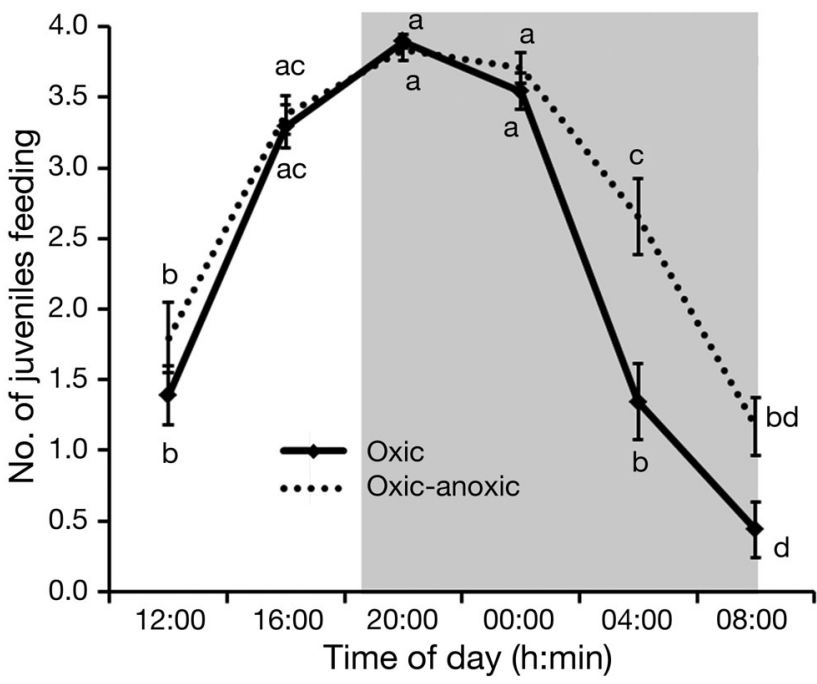

Fig. 4. Mean $( \pm \mathrm{SE})$ number of juvenile Holothuria scabra (n $=4$ ) observed to be feeding on the sediment surface and the tank walls when reared under 2 contrasting sediment redox regimes: fully aerobic (oxic) and stratified (oxic-anoxic). Different lower case letters indicate significant differences between the number of juveniles feeding over time for each redox regime (Tukey's HSD post hoc test). The shaded area represents dark hours (17:40-07:40 h, local time)

$626.89 \pm 35.44 \mathrm{~g} \mathrm{~m}^{-2}$ at the end of the trial compared with $449.22 \pm 14.24 \mathrm{~g} \mathrm{~m}^{-2}$ for oxic treatments (multifactor ANOVA, $F_{1,24}=21.05, \mathrm{p}<0.001$; Fig. 3). Significant differences in growth rates were principally related to the depth of the oxic-anoxic interface (multiple regression, $\mathrm{r}^{2}=0.40 ; \beta=0.63 ; \mathrm{p}<0.001$ ) and the sediment redox potential (multiple regression, $\mathrm{r}^{2}$ $=0.26 ; \beta=-0.51 ; \mathrm{p}<0.001$ ). The manipulated redox regime was the foremost factor responsible for this difference in growth rate and final biomass production, as sediment depth and particle size had no significant effect on growth rate or biomass density.

\section{Behaviour}

Time and the interaction between sediment redox regime and time significantly affected all categories of observed burial behaviour and activity level defined in Table $2(\mathrm{p}<0.05)$. Animals reared in oxic-anoxic treatments displayed a shorter burial cycle, remaining on the surface (exposed) for longer in the early morning before burying (repeated measures ANOVA, $\left.F_{3.43,82.40}=7.27, \mathrm{p}<0.001\right)$ and spent significantly more time feeding (repeated measures ANOVA, $F_{2.59,62.21}=4.85, \mathrm{p}=0.006$; Fig. 4). The most notable differences in burial cycle and feeding activity occurred in the early morning between midnight and 08:00 h, when animals in oxic treatments ceased feeding and began to bury earlier compared with the animals in oxic-anoxic treatments; for example, at $04: 00 \mathrm{~h} 2.66 \pm 0.27$ animals were still feeding on the oxic-anoxic sediment compared with $1.34 \pm 0.27$ feeding on the oxic sediment (Fig. 4).

\section{Proximate composition}

The sediment redox regime significantly affected the sea cucumber biochemical composition (Table 5), with crude lipid and carbohydrate content significantly higher in animals reared in oxic treatments (multifactor ANOVA, $F_{1,16}=7.72, \mathrm{p}=0.013$ and $F_{1,16}$ $=8.16, \mathrm{p}=0.011$ for lipid and carbohydrate, respectively). In contrast, ash content was lower in animals reared in oxic treatments; $62.82 \pm 1.59 \%$ compared with $67.03 \pm 1.10 \%$ in oxic-anoxic treatments (multifactor ANOVA, $F_{1,16}=5.01, \mathrm{p}=0.04$ ). Redox regime and substrate depth interacted to account for a significant difference in crude fibre (multifactor ANOVA, $F_{1,16}=7.34, \mathrm{p}=0.015$; Table 5); however, there were no significant differences in protein, moisture, or gross energy content (multifactor ANOVA, p > 0.05). The sediment redox regime was again the causative factor for ash, lipid and carbohydrate content.

\section{DISCUSSION}

This study investigated the growth responses of juvenile Holothuria scabra, a commercially and ecologically important sea cucumber species, cultured with surficial sediment of manipulated physicochemical characteristics, namely, sediment depth, particle size and redox regime. The redox regime (either: oxic-anoxic or fully oxic) was the principal factor affecting sea cucumber growth, biomass production, behaviour and biochemical composition, in addition to driving differences in sediment quality (e.g. C/N ratio, chlorophyll a concentration). The oxic-anoxic treatments supported an approximately $30 \%$ increase in growth rate relative to the fully oxic sediments that had, by the end of the trial, translated into a substantial increase in sea cucumber biomass production $(626.89 \pm 35.44$ versus $454.84 \pm 14.29 \mathrm{~g}$ $\mathrm{m}^{-2}$ ). In the oxic sediment system, sea cucumbers exhibited negative allometric growth, with individual growth rates decreased to zero or becoming regressive once the carrying capacity was exceeded (454.84 $\pm 14.29 \mathrm{~g} \mathrm{~m}^{-2}$ at Day 54). Indeed, in contrast to the oxic treatments, the biomass carrying capacity 
Table 5. Holothuria scabra. Mean $( \pm$ SE) proximate composition of sea cucumbers reared on substrates with 2 contrasting redox regimes, each with different depths and particle sizes (fine particles: 125-250 $\mu \mathrm{m}_{\text {; }}$ medium particles: 250-500 $\mu \mathrm{m}$ ). Different super-scripts indicate significant differences (multifactor ANOVA, $\mathrm{p}<0.05$ ) identified by Duncan's multiple range tests

\begin{tabular}{|c|c|c|c|c|c|c|c|c|c|}
\hline $\begin{array}{l}\text { Redox } \\
\text { regime }\end{array}$ & $\begin{array}{l}\text { Depth } \\
\text { (cm) }\end{array}$ & $\begin{array}{l}\text { Particle } \\
\text { size }\end{array}$ & $\begin{array}{c}\text { Crude } \\
\text { protein }(\%)\end{array}$ & $\begin{array}{l}\text { Crude } \\
\text { lipid (\%) }\end{array}$ & $\begin{array}{l}\text { Crude } \\
\text { fibre (\%) }\end{array}$ & $\begin{array}{c}\text { Carbo- } \\
\text { hydrate (\%) }\end{array}$ & $\begin{array}{l}\text { Ash } \\
(\%)\end{array}$ & $\begin{array}{l}\text { Moisture } \\
(\%)\end{array}$ & $\begin{array}{c}\text { Gross } \\
\text { energy (\%) }\end{array}$ \\
\hline Oxic & 2 & Fine & $21.40 \pm 3.21$ & $0.89 \pm 0.15^{a}$ & $0.40 \pm 0.08^{\mathrm{ab}}$ & $13.91 \pm 1.41^{\mathrm{ab}}$ & $63.39 \pm 3.89^{\mathrm{ab}}$ & $87.83 \pm 1.66$ & $4.89 \pm 0.88$ \\
\hline Oxic & 2 & Medium & $23.83 \pm 0.11$ & $0.84 \pm 0.04^{\mathrm{a}}$ & $0.50 \pm 0.01^{\mathrm{b}}$ & $16.39 \pm 1.36^{\mathrm{b}}$ & $58.45 \pm 1.43^{\mathrm{b}}$ & $88.82 \pm 0.58$ & $5.76 \pm 0.50$ \\
\hline Oxic & 4 & Fine & $21.91 \pm 1.92$ & $0.87 \pm 0.15^{\mathrm{a}}$ & $0.45 \pm 0.17^{\mathrm{ab}}$ & $13.82 \pm 0.41^{\mathrm{ab}}$ & $62.95 \pm 1.72^{\mathrm{ab}}$ & $88.64 \pm 0.53$ & $5.09 \pm 0.23$ \\
\hline Oxic & 4 & Medium & $18.73 \pm 2.61$ & $0.74 \pm 0.04^{\mathrm{ab}}$ & $0.23 \pm 0.04^{\mathrm{a}}$ & $13.78 \pm 2.10^{\mathrm{ab}}$ & $66.51 \pm 4.34^{\mathrm{ab}}$ & $87.07 \pm 1.69$ & $4.07 \pm 0.65$ \\
\hline Oxic-anoxic & C 2 & Fine & $18.35 \pm 2.11$ & $0.65 \pm 0.08^{\mathrm{ab}}$ & $0.22 \pm 0.05^{\mathrm{a}}$ & $11.47 \pm 0.70^{\mathrm{a}}$ & $69.32 \pm 2.84^{\mathrm{a}}$ & $87.61 \pm 0.74$ & $4.14 \pm 0.59$ \\
\hline Oxic-anoxic & C 2 & Medium & $21.26 \pm 1.61$ & $0.77 \pm 0.01^{\mathrm{ab}}$ & $0.34 \pm 0.03^{\mathrm{ab}}$ & $13.26 \pm 1.30^{\mathrm{ab}}$ & $64.37 \pm 1.81^{\mathrm{ab}}$ & $90.13 \pm 0.17$ & $4.85 \pm 0.34$ \\
\hline Oxic-anoxic & C 4 & Fine & $18.69 \pm 1.70$ & $0.51 \pm 0.03^{b}$ & $0.39 \pm 0.05^{\mathrm{ab}}$ & $11.54 \pm 0.46^{\mathrm{a}}$ & $68.87 \pm 1.82^{\mathrm{a}}$ & $88.51 \pm 0.65$ & $4.00 \pm 0.44$ \\
\hline Oxic-anoxic & C 4 & Medium & $20.96 \pm 2.00$ & $0.72 \pm 0.07^{\mathrm{ab}}$ & $0.54 \pm 0.06^{b}$ & $12.24 \pm 0.32^{\mathrm{a}}$ & $65.55 \pm 1.67^{\mathrm{ab}}$ & $88.92 \pm 0.60$ & $4.89 \pm 0.56$ \\
\hline
\end{tabular}

of the oxic-anoxic sediments had not been reached by the trial end and growth rates remained positive. Populations of soft sediment deposit-feeders such as sea cucumbers are commonly food limited (Lopez \& Levinton 1987, Josefson 1998); however, the growth limitation experienced in the oxic system cannot be explained by differences in the feeding regimen since rations were standardised across all treatments and adjusted on a 2-weekly basis in the same way for each treatment.

All stages in organic matter degradation involve the interaction of organisms, resource quality, physical and chemical environmental conditions (Anderson 1987). Consequently, deposit-feeder nutrition is fundamentally related to the decomposition of particulate organic matter (detritus) (Tenore et al. 1982, Rice \& Rhoads 1989), with strong feedback loops existing between deposit-feeders, their food and their chemical environment (Herman et al. 1999). The oxygenation status of marine sediments is the main factor influencing the rate and intensity of organic matter decomposition, since the presence or absence of oxygen influences microbial metabolism and enzymatic capacity. In oxidised sediment, organic matter is rapidly decomposed by aerobic heterotrophs which have the enzymatic capacity to perform complete oxidation of complex organic substrates via the tricarboxylic acid cycle (Kristensen 2001). In anoxic sediments, organic matter is degraded more slowly by an anaerobic food chain involving the sequential and/or simultaneous activities of a mutualistic consortium of anaerobic bacteria, since no single type of anaerobic bacterium seems capable of complete mineralisation (Middelburg et al. 1993, Fenchel et al. 1998). While oxygen can be substituted by other forms of chemically bound oxygen in anaerobic respiration, there is no equivalent of molecular oxygen that can fulfil its function in the primary rate-limiting hydrolytic step in organic matter decomposition (Kristensen et al. 1995).

In the oxic treatments all sources of autochthonous and allochthonous organic matter would have been rapidly respired and lost as $\mathrm{CO}_{2}$. The higher $\mathrm{C} / \mathrm{N}$ ratios in the oxic-anoxic treatments indicate a greater pool of refractory organic matter from which bacteria have preferentially hydrolysed nitrogenrich molecules, i.e. nucleic acids and proteins. The predominately anaerobic conditions of the oxicanoxic sediments, which mirror the natural habitat of $H$. scabra, are likely to have provided a steady release of bioavailable food resources, thereby supporting a higher secondary biomass. Further, sea cucumbers are known to absorb dissolved organics across the epithelium (Jangoux \& Lawerence 1982) or through the respiratory trees as part of a bipolar feeding strategy (Jaeckle \& Strathmann 2013). Therefore, the more refractory organic matter and energy-rich fermentation products may have functioned as a more durable and persistent food source (i.e. an overall increase in food quantity) in the oxicanoxic treatments, contributing to long-term productivity despite the apparent lower nutritive quality (Schroeder 1987, Karlsen 2010).

The influence of microbial communities on the rate and pathways of nitrogen cycling is also sensitive to the presence or absence of oxygen (Aller \& Aller 1998). In the oxic sediment layer, ammonium is oxidised in a step-wise reaction to nitrite and subsequently to nitrate, which is then reduced to free nitrogen gas by denitrification in the anoxic layer (Vanderborght \& Billen 1975). Nitrification rate is regulated by the availability of $\mathrm{NH}_{4}{ }^{+}$and oxygen (Fenchel et al. 1998). The nitrification efficiency would therefore have been high in the oxic sediment system where oxygen penetration was maximised and $\mathrm{NH}_{4}{ }^{+}$production rapid. The significantly lower 
nitrite concentration in water from the $4 \mathrm{~cm}$ oxic treatment tanks indicates that nitrite, as the intermediate product in nitrification, may have been oxidised more efficiently to nitrate by nitrite-oxidising bacteria that proliferated in the sediment under increased oxygen concentrations.

The greater microphytobenthic standing stock in the oxic treatments is likely to have resulted from enhanced nitrate remineralisation. In shallow euphotic benthic systems there is tight coupling between autotrophic and heterotrophic processes, and in wellmixed systems this coupling can be intense (Fenchel et al. 1998, Herman et al. 1999). Algal mats are efficient at assimilating nutrients from the sediment surface, and an increased nutrient supply may affect the dominance of bottom-up forces leading to overgrowth by algal mats (Levinton \& Kelaher 2004). While nitrate availability is likely to have had the most impact on microphytobenthic production, increased concentrations of dissolved inorganic carbon resulting from the rapid, aerobic oxidation of organic matter may have also played a role (Ludden et al. 1985).

Deposit-feeding holothurians are broadly adapted to process large quantities of sediments of low nutritional quality (Lopez \& Levinton 1987, Roberts et al. 2000); however, they exhibit a general plasticity of behavioural and feeding strategies in response to variations in resource availability (Roberts et al. 2000). In the oxic sediment, animals spent less time feeding and spent longer periods buried. In a more detailed behavioural study, Yu (2012) made similar observations, in that juvenile $H$. scabra reared on oxic sediments exhibited much lower feeding and activity levels. Sea cucumbers have a behavioural capacity to alter their ingestion rate in response to food quality. The 'optimal ingestion rate' predicts that the ingestion rate increases with increasing food value (Taghon 1981, Taghon \& Jumars 1984), while 'compensatory feeding' predicts that the ingestion rate decreases with increasing food value (Calow 1977, Cammen 1979). Apparent compensatory slowdowns in ingestion rates in response to rich food sources such as benthic diatoms have been observed for deposit-feeders including sea cucumbers (Cammen 1979, Lopez \& Levinton 1987, Zamora \& Jeffs 2011). As their net gain of energy and nutrients is determined by foraging and digestion, sea cucumbers in the oxic treatments may have decreased their feeding rate and activity levels due to the limited need to forage in response to the abundant microphytobenthic production. The demonstration by Phillips (1984) that compensatory regulation of energy intake can be consistent with an optimal foraging model may explain the behaviour and growth limitation of sea cucumbers in the oxic treatments.

The higher lipid and carbohydrate contents of animals reared in the oxic sediment system may be a reflection of the higher quality of food resources, such as benthic diatoms, which have a relatively high intrinsic food value and assimilation efficiencies (Yingst 1976, Watanabe et al. 2012). As lipids and carbohydrates are believed to be the primary nutrient reserves in sea cucumbers (Krishnan 1968, Féral 1985), it would appear that animals were allocating the products of digestion to storage as opposed to using them for maintenance and growth. This type of compensatory feeding is typical in some depositfeeders in the face of abundant food reserves and allows them to regulate their intake of energy and store excess nutrients for later use (Calow 1977).

The current study highlights a facet of sea cucumber feeding ecology that has profound, and arguably conflicting, repercussions for their application as bioremediation organisms and for improvements in farming practices. Achieving good oxygenation status is a common and inexpensive stimulatory strategy to accelerate the aerobic microbial decomposition of organic-rich sediments; yet based on the current results this approach (driven by oxic sediment redox regimes) limits and retards the growth and eventual biomass yield of sea cucumbers by rapid mineralisation of nutrients, which would otherwise be available for assimilation into sea cucumber biomass. Conversely, where sediment is managed to maximise sea cucumber biomass yield (employing a stratified redox regime), the rate of organic matter mineralisation is considerably slowed (Torres-Beristain et al. 2006). Thus, from a commercial perspective maximising the system's bioremediating capacity occurs at the expense of a valuable cash crop, while compromising environmental remediation enhances economic return. In reality, this need not be an either/or scenario. A 'hybrid' sediment management system could be conceived wherein oxygenation strategies could be selectively optimised over the times and spatial scales that may provide an acceptable compromise. Alternatively, the organic loading of the oxic system (i.e. the feeding regime) may have been overly conservative. In a commercial situation, the sediment-based effluent treatment system would receive frequent waste addition, comprising principally waste feed and faeces. In this scenario, wherein the rate of organic loading exceeds the rate of carbon loss, oxic sediment systems would have an increased and hitherto untapped capacity to support significantly greater sea cucumber growth and biomass production. 
Oxygenation of subsurface sediments and the removal of metabolites are considered the 2 most important underlying mechanisms for stimulating carbon oxidation in controlled sediment regimes (Kristensen 2001). In the current study oxic sediment systems experienced increased rates of organic matter decomposition, including the more refractory organic matter pools. This will have enhanced porewater column solute exchange, thereby contributing towards an overall reduction in food resource availability to deposit-feeding sea cucumbers and providing a proximal cause for limited growth. Strictly aerobic detrital systems in nature are rare (Plante et al. 1990) and are unlikely to be a suitable medium for deposit-feeder growth in the long term, unless the rate of organic loading matches the rate of carbon loss (respiration and organism growth). In contrast, the oxic-anoxic system, which resembles the natural habitat of $H$. scabra and supported both aerobic and anaerobic mineralisation pathways, supported strong and sustained sea cucumber growth, presumably due to the presence of more refractory organic matter. Consequently, we conclude that the observed divergence in biomass carrying capacity was driven by differences in inorganic nutrient mineralisation and cycling between the contrasting redox regimes with the oxic-anoxic system supporting a more durable food resource. Future research should focus on determining the quality, quantity and frequency of the addition of waste effluents to support the optimal production of deposit-feeders in land-based bioremediation systems in tandem with a more varied approach to oxygenation integrated over space and time.

Acknowledgements. This research was funded by a Biotechnology and Biological Sciences Research Council (BBSRC) Industrial CASE Studentship to G.R. (Grant Code BB/J01141X/1) with HIK Abalone Farm Pty as the CASE partner, and with additional contributions from the THRIP program of the National Research Foundation, South Africa (Grant Number TP2011070800007). The work was conceptualised and funding was secured by G.R., C.L.W.J., M.J.S. and S.M.S. Experiments were performed by G.R. Data were analysed by G.R. and C.L.W.J., the manuscript was written by G.R. and G.S.C. and edited by M.J.S., C.L.W.J. and S.M.S.

\section{LITERATURE CITED}

Alexander M (1999) Biodegradation and bioremediation, 2nd edn. Academic Press, New York, NY

Aller RC (1994) Bioturbation and remineralization of sedimentary organic-matter-effects of redox oscillation. Chem Geol 114:331-345

Aller RC, Aller JY (1998) The effect of biogenic irrigation intensity and solute exchange on diagenetic reaction rates in marine sediments. J Mar Res 56:905-936

Anderson JM (1987) Production and decomposition in aquatic ecosystems and implications for aquaculture. In: Moriarty DJW, Pullin RSV (eds) Detritus and microbial ecology in aquaculture. ICLARM, Manila, p 123-145

AOAC (Association of Official Analytical Chemists) (2010) Official methods of analysis of AOAC International, 18th edn. AOAC, Washington, DC

Baskar BK (1994) Some observations on biology of the holothurian Holothuria (Metriatyla) scabra (Jaeger). CMFRI Bull 46:39-43

Battaglene SC, Seymour JE, Rajagopalan M, Ramofafia C (1999) Culture of tropical sea cucumbers for stock restoration and enhancement. Aquaculture 178:293-322

Calow P (1977) Ecology, evolution and energetics: a study in metabolic adaptation. Adv Ecol Res 10:1-62

Cammen LM (1979) Ingestion rate: an empirical model for aquatic deposit feeders and detritivores. Oecologia 44: 303-310

Chávez-Crooker P, Obreque-Contreras J (2010) Bioremediation of aquaculture wastes. Curr Opin Biotechnol 21: 313-317

Colleran E (1997) Uses of bacteria in bioremediation. In: Sheehan D (ed) Methods in biotechnology, bioremediation protocols, Vol 2. Humana Press, Clifton, NJ, p 3-22

Fenchel T, King GM, Blackburn TH (1998) Bacterial biogeochemistry. The ecophysiology of mineral cycling. Academic Press, San Diego, CA

Féral JP (1985) Effect of short-term starvation on the biochemical composition of the apodous holothurian Leptosynapta galliennei (Echinodermata): possible role of dissolved organic material as an energy source. Mar Biol 86: 297-306

Gifford S, Dunstan RH, O'Connor W, Roberts T, Toia R (2004) Pearl aquaculture - profitable environmental remediation? Sci Total Environ 319:27-37

Grassle JF, Grassle JP (1974) Opportunistic life histories and genetic systems in marine benthic polychaetes. J Mar Res 32:253-284

Herman PMJ, Middelburg JJ, Van de Koppel J, Heip CHR (1999) Ecology of estuarine macrobenthos. In: Nedwell DB, Raffaelli DG (eds) Advances in ecological research, Vol 29. Academic press, New York, NY, p 195-240

> Jaeckle WB, Strathmann RR (2013) The anus as a second mouth: anal suspension feeding by an oral deposit-feeding sea cucumber. Invertebr Biol 132:62-68

Jangoux M, Lawerence JM (1982) Echinoderm nutrition. Balkema, Rotterdam

Jaubert JM (2008) Scientific considerations on a technique of ecological purification that made possible the cultivation of reef-building corals in Monaco. In: Leewis RJ, Janse $M$ (eds) Advances in coral husbandry in public aquariums. Burgers' Zoo, Arnhem, p 155-126

Jeffrey SW, Welshmeyer NA (1997) Spectrophotometric and fluorometric equations in common use in oceanography. In: Jeffrey SW, Mantoura RFC, Wright SW (eds) Phytoplankton pigments in oceanography, monographs on oceanographic methodology No. 10. UNESCO Publishing, Paris, p 597-615

> Josefson AB (1998) Resource limitation in marine soft sediments - differential effects of food and space in the association between the brittle-star Amphiura filiformis and the bivalve Mysella bidentata? Hydrobiologia 375/376: 297-305 
Karlsen A (2010) Benthic use of phytoplankton blooms: uptake, burial and biodiversity effects in a species-poor system. Stockholm University

Kim JK, Duston J, Corey P, Garbary DJ (2013) Marine finfish effluent bioremediation: effects of stocking density and temperature on nitrogen removal capacity of Chondrus crispus and Palmaria palmata (Rhodophyta). Aquaculture 414/415:210-216

Krishnan S (1968) Histochemical studies on reproductive and nutritional cycles of the holothurian, Holothuria scabra. Mar Biol 2:54-65

Kristensen E (2000) Organic matter diagenesis at the oxic/anoxic interface in coastal marine sediments, with emphasis on the role of burrowing animals. Hydrobiologia 426:1-24

Kristensen E (2001) Impact of polychaetes (Nereis spp. and Arenicola marina) on carbon biogeochemistry in coastal marine sediments. Geochem Trans 2:92

Kristensen E, Ahmed SI, Devol AH (1995) Aerobic and anaerobic decomposition of organic matter in marine sediment: Which is fastest? Limnol Oceanogr 40: 1430-1437

> Levinton J, Kelaher B (2004) Opposing organizing forces of deposit-feeding marine communities. J Exp Mar Biol Ecol 300:65-82

Lopez GR, Levinton JS (1987) Ecology of deposit-feeding animals in marine sediments. Q Rev Biol 62:235-260

$>$ Ludden E, Admiraal W, Colijn F (1985) Cycling of carbon and oxygen in layers of marine microphytes - a simulation model and its ecophysiological implications. Oecologia 66:50-59

Mercier A, Battaglene SC, Hamel JF (1999) Daily burrowing cycle and feeding activity of juvenile sea cucumbers Holothuria scabra in response to environmental factors. J Exp Mar Biol Ecol 239:125-156

> Mermillod-Blondin F, Rosenberg R (2006) Ecosystem engineering: the impact of bioturbation on biogeochemical processes in marine and freshwater benthic habitats. Aquat Sci 68:434-442

Michio K, Kengo K, Yasunori K, Hitoshi M, Takayuki Y, Hideaki Y, Hiroshi S (2003) Effects of deposit feeder Stichopus japonicus on algal bloom and organic matter contents of bottom sediments of the enclosed sea. Mar Pollut Bull 47:118-125

Middelburg JJ, Vlug T, Vandernat F (1993) Organic matter mineralization in marine systems. Global Planet Change 8:47-58

> Moriarty DJW (1982) Feeding of Holothuria atra and Stichopus chloronotus on bacteria, organic carbon and organic nitrogen in sediments of the Great Barrier Reef. Aust J Mar Freshw Res 33:255-263

Moriarty DJW (1987) Methodology for determining biomass and productivity of microorganisms in detrital food webs. In: Moriarty DJW, Pullin RSV (eds) Detritus and microbial ecology in aquaculture. International Center for Living Aquatic Resources Management, Bellagio, Como, p 4-31

Moser BK, Stevens GR (1992) Homogeneity of variance in the two-sample means test. Am Stat 46:19-21

> Muradov N, Taha M, Miranda AF, Kadali K and others (2014) Dual application of duckweed and azolla plants for wastewater treatment and renewable fuels and petrochemicals production. Biotechnol Biofuels 7:30

Palmer PJ (2010) Polychaete-assisted sand filters. Aquaculture 306:369-377
Phillips NW (1984) Compensatory intake can be consistent with an optimal foraging model. Am Nat 123:867-872

Pitt R, Thu NTX, Mihn MD, Phuc HN (2001) Preliminary sandfish growth trials in tanks, ponds and pens in Vietnam. SPC Beche-de-mer Inf Bull 15:17-27

Plante CJ, Jumars PA, Baross JA (1990) Digestive associations between marine detritivores and bacteria. Annu Rev Ecol Syst 21:93-127

Pullin RSV (1987) Session on manipulation of detrital systems for aquaculture, chairman's overview. In: Moriarty DJW, Pullin RSV (eds) Detritus and microbial ecology in aquaculture. International Center for Living Aquatic Resources Management, Bellagio, Como, p 420

Purcell SW (2014) Value, market preferences and trade of beche-de-mer from Pacific island sea cucumbers. PLoS ONE 9:e95075

Purcell SW, Polidoro BA, Hamel JF, Gamboa RU, Mercier A (2014) The cost of being valuable: predictors of extinction risk in marine invertebrates exploited as luxury seafood. Proc R Soc B 281:20133296

Quinn GP, Keough MJ (2012) Experimental design and data analysis for biologists. Cambridge University Press, Cambridge

Raj L (1998) Photo-identification of Stichopus mollis. SPC Beche-de mer Inf Bull 10:29-31

Rice DL, Rhoads DC (1989) Early diagenesis of organic matter and the nutritional value of sediment. Lect Notes Coast Estuar Stud 31:59-97

Roberts D, Gebruk A, Levin V, Manship BAD (2000) Feeding and digestive strategies in deposit-feeding holothurians. Oceanogr Mar Biol 38:257-310

Robinson G, Slater M, Jones CLW, Stead S (2013) Role of sand as substrate and dietary component in recirculating aquaculture systems for juvenile sea cucumber Holothuria scabra. Aquaculture 392-395:23-25

Schroeder GL (1987) Carbon pathways in aquatic detrital systems. In: Moriarty DJW, Pullin RSV (eds) Detritus and microbial ecology in aquaculture. ICLARM, Manila, p 420

Solorzano L (1969) Determination of ammonia in natural waters by phenol hypochlorite method. Limnol Oceanogr 14:799-801

Stahlberg C, Bastviken D, Svensson BH, Rahm L (2006) Mineralisation of organic matter in coastal sediments at different frequency and duration of resuspension. Estuar Coast Shelf Sci 70:317-325

> Taghon GL (1981) Beyond selection: optimal ingestion rate as a function of food value. Am Nat 118:202-214

Taghon GL, Jumars PA (1984) Variable ingestion rate and its role in optimal foraging behavior of marine deposit feeders. Ecology 65:549-558

Tenore KR (1981) Organic nitrogen and caloric content of detritus. I. Utilization by the deposit-feeding polychaete, Capitella capitata. Estuar Coast Shelf Sci 12:39-47

Tenore KR, Cammen L, Findlay SEG, Phillips N (1982) Perspectives of research on detritus - Do factors controlling the availability of detritus to macro-consumers depend on its source? J Mar Res 40:473-490

Torres-Beristain B, Verdegem M, Kerepeczki E, Verreth J (2006) Decomposition of high protein aquaculture feed under variable oxic conditions. Water Res 40:1341-1350

Uthicke S (2001) Nutrient regeneration by abundant coral reef holothurians. J Exp Mar Biol Ecol 265:153-170

- Vanderborght JP, Billen G (1975) Vertical distribution of nitrate concentration in interstitial water of marine sedi- 
ments with nitrification and denitrification. Limnol Oceanogr 20:953-961

Watanabe S, Kodama M, Zarate JM, Lebata-Ramos MJH, Nievales MFJ (2012) Ability of sandfish (Holothuria scabra) to utilise organic matter in black tiger shrimp ponds. In: Hair CA, Pickering TD, Mills DJ (eds) Proceedings Asia-Pacific tropical sea cucumber aquaculture. Australian Centre for International Agricultural Research, Canberra, p 113-120

Wolkenhauer SM (2008) Burying and feeding activity of adult Holothuria scabra (Echinodermata: Holothuroidea) in a controlled environment. SPC Beche-de-mer Inf Bull $27: 25-28$

Wolkenhauer SM, Uthicke S, Burridge C, Skewes T, Pitcher $\mathrm{R}$ (2010) The ecological role of Holothuria scabra (Echinodermata: Holothuroidea) within subtropical sea-

Editorial responsibility: Adam Hughes, Oban, UK grass beds. J Mar Biol Assoc UK 90:215-223

Yingst JY (1976) The utilization of organic matter in shallow marine sediments by an epibenthic deposit-feeding holothurian. J Exp Mar Biol Ecol 23:55-69

$\mathrm{Yu}$ W (2012) The effect of a plenum on the growth and behaviour of cultured sandfish, Holothuria scabra. Rhodes University, Grahamstown

Zamora LN, Jeffs AG (2011) Feeding, selection, digestion and absorption of the organic matter from mussel waste by juveniles of the deposit-feeding sea cucumber, Australostichopus mollis. Aquaculture 317:223-228

Zhang X, Zhang W, Xue L, Zhang B, Jin M, Fu W (2010) Bioremediation of bacteria pollution using the marine sponge Hymeniacidon perlevis in the intensive mariculture water system of turbot Scophthalmus maximus. Biotechnol Bioeng 105:59-68

Submitted: May 8, 2015; Accepted: October 26, 2015

Proofs received from author(s): December 2, 2015 